\title{
SUMBERDAYA AIR BAGI PEMENUHAN MASYARAKAT DI KABUPATEN TASIKMALAYA JAWA BARAT
}

\section{Priyo Hartanto}

\begin{abstract}
ABSTRAK : Keterdapatan sumberdaya air di wilayah Kabupaten Tasikmalaya perlu diketahui dengan pasti sehingga informasi tersebut dapat menunjang pembangunan wilayah ini. Untuk mengetahui keterdapatan sumberdaya air, penelitian dilakukan dengan memanfaatkan data kondisi geologi, daerah aliran sungai (DAS), iklim dan kebutuhan air. Untuk mengetahui kebutuhan air, dilakukan pendekatan data kependudukan. Bulan kering berlangsung pada bulan Agustus dan bulan basah antara bulan September sampai Juli. Curah hujan rata-rata bulanan berkisar antara 92-320 mm, dengan curah hujan tahunan $2532 \mathrm{~mm}$. Evapotranspirasi bulanan berkisar antara 96-116 mm, sedangkan jumlah setahun $1307 \mathrm{~mm}$. Cadangan air yang ada di Kabupaten Tasikmalaya berkisar antara $23 \mathrm{~mm}$ sampai $207 \mathrm{~mm}$, dengan luas wilayah 2680,5 $\mathrm{km}^{2}$, sehingga cadangan air bulanan berkisar antara $1.306 .515 \mathrm{~m}^{3}$ hingga $11.758 .655 \mathrm{~m}^{3}$. Kebutuhan air untuk domestik adalah 222.150 $\mathrm{m}^{3} /$ hari. Kelebihan air $169.805 \mathrm{~m}^{3} / \mathrm{hr}$ dapat digunakan untuk pertanian sekitar $117.920 \mathrm{Ha}$ atau sekitar 393.067 Ha lahan palawija.
\end{abstract}

Kata Kunci:Keterdapatan, sumberdaya air, daerah aliran sungai (DAS), curah hujan, evapotranspirasi, neraca air, cadangan air.

Naskah masuk : 15 Oktober 2012

Naskah diterima : 8 Desember 2012

Priyo Hartanto

Pusat Penelitian Geoteknologi LIPI

Komplek LIPI, Jl. Sangkuriang, Bandung 40135

E-mail : hartanto@geotek.lipi.go.id
ABSTRACT : Occurrence water resources in Tasikmalaya District need to be known with certainty that the information can support the development of the region. To find out occurrence water resources conducted by using data about geological conditions, river basin, climate and water needs. To determine the water needs to approach population data. Dry month occurred on August, while wet months occurred on the period of September to July. The average monthly precipitation is ranged between 92-320 $\mathrm{mm}$ with total of yearly precipitation $2,532 \mathrm{~mm}$. The monthly precipitation is ranged between 96$116 \mathrm{~mm}$, with total of yearly evapotranspiration about 1,307 mm. Water reserves in Tasikmalaya District is ranged between 23 to $207 \mathrm{~mm}$, covering in the area of $2,680.5 \mathrm{~km}^{2}$, then total of reserved water is $1,306,515 \mathrm{~m}^{3}$ to $11,758,655 \mathrm{~m}^{3}$. Water for domestic needs is $222.150 \mathrm{~m}^{3} /$ day. $169.805 \mathrm{~m}^{3} /$ day excess water can be used for approximately 117.920 hectares agriculture or approximately 393.067 hectares of land crops.

Keywords: Occurrence, water resources, river basin, precipitation, evapotranspiration, water balance, water reserved.

\section{PENDAHULUAN}

Sumber daya air sangat dibutuhkan dalam rencana pengembangan suatu wilayah. Arah kebijakan pembangunan Kabupaten Tasikmalaya salah satunya adalah mewujudkan perekonomian yang tangguh berbasis pedesaan dengan keunggulan agribisnis (Pemkab Tasikmalaya, 2012). Sektor pertanian masih menjadi sektor unggulan dan mendorong berkembangnya sektor unggulan lainnya di Tasikmalaya (Sonjaya, 2008). Kabupaten Tasikmalaya memiliki potensi sumberdaya alam hayati maupun non-hayati yang potensial untuk dikembangkan. Kabupaten Tasikmalaya menetapkan kawasan yang terkait dengan perlindungan lingkungan yang tertera dalam Perda RTRW No. 2 Tahun 2012. Daerah penelitian terbagi menjadi dua kawasan yaitu kawasan hutan lindung yang mencapai luas 
$173.686,72$ ha atau $64,12 \%$ dan kawasan budidaya seluas 97.195,04 ha atau 35,88\%. Kawasan hutan lindung berada pada kesatuan pemangkuan hutan kabupaten. Kawasan hutang lindung di Kabupaten Tasikmalaya seluas kurang lebih 16.882 hektar yang meliputi kecamatan Ciawi, Cigalontang, Cisayong, Kadipaten, Leuwisari, Padakembang, Puspahiang, Salawu, Sariwangi, Sukasenang, Sukaratu dan Taraju. Kawasan konservasi perairan yang berfungsi untuk pusat pemberdayaan ikan secara berkelanjutan seluas kurang lebih 483 hektar, meliputi Kecamatan Cipatujah dan Karangnunggal. Kawasan resapan air seluas 13.417 hektar berfungsi untuk menjaga dan memelihara kawasan resapan air terhadap kawasan di bawahnya.

Permasalahan yang muncul adalah apakah keterdapatan sumberdaya air di wilayah
Tasikmalaya dapat mendukung kebijakan yang telah ditetapkan oleh Pemerintah Daerah setempat, baik untuk kebutuhan domestik maupun lainnya. Untuk mendukung arah kebijakan tersebut, perlu didukung data potensi sumberdaya air di wilayah ini.

Penelitian ini dimaksudkan untuk mengetahui keterdapatan sumberdaya air di Kabupaten Tasikmalaya, sehingga dengan diketahui keterdapatan suberdaya air dapat mendukung arah kebijakan yang sudah digariskan wilayah ini. Pengertian keterdapatan disini adalah jumlah total keterdapatan air di suatu tempat (Djuwansah dan Rusydi, 2012). Pendekatan yang dilakukan dalam penelitian ini memanfaatkan data yang terkait dengan sumberdaya air, kondisi geologi, daerah aliran sungai (DAS), iklim dan kebutuhan air.

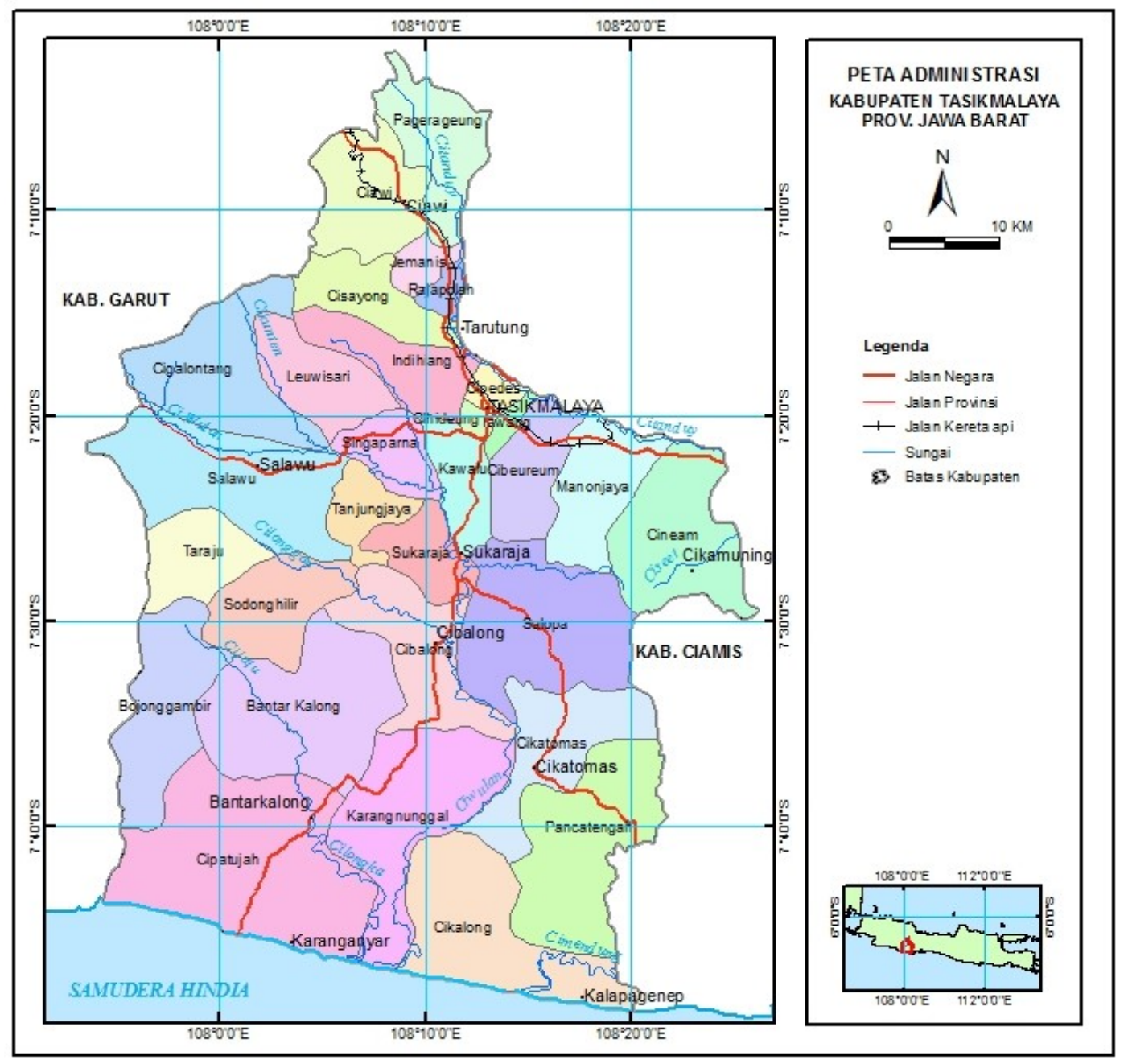

Gambar 1. Peta lokasi penelitian 


\section{Lokasi Penelitian}

Daerah Kabupaten Tasikmalaya yang terdiri atas 39 kecamatan memiliki luas wilayah 270.881 hektar dan terletak pada elevasi antara 0-3.000 meter di atas permukaan laut. Daerah ini secara geografi terletak pada koordinat $07^{\circ} 02^{`} 29^{\prime \prime}-07^{\circ}$ $49^{`} 08^{\prime \prime}$ LS dan $107^{\circ} 54^{\prime} 10^{\prime \prime}-108^{\circ} 26^{`} 42^{\prime \prime} \mathrm{BT}$. Daerah ini secara administrasi berbatasan dengan Kabupaten Majalengka dan Ciamis di sebelah utara, Samudra Indonesia di selatan, Kabupaten Ciamis di sebelah timur dan Kabupaten Garut di sebelah barat (Gambar 1).

Keadaaan topografi Kabupaten Tasikmalaya merupakan daerah perbukitan, dataran dan daerah yang agak landai sampai landai. Morfologi daerah penelitian dapat dikelompokkan menjadi 4 (empat), yaitu (i) satuan perbukitan vulkanik, (ii) satuan perbukitan sedimen, (iii) satuan karst dan (iv) satuan dataran (Hadi, 1997).

\section{GEOLOGI DAN HIDROLOGI}

Batuan yang menyusun wilayah Kabupaten Tasikmalaya meliputi endapan gunungapi (QT) sebanyak 30\% dan endapan sedimenter (Tm) sebanyak 70\%. Endapan gunungapi (QT) terdiri atas endapan Gunung Api Tua (QTv) dan Gunung Api Muda (Qy) yang tersebar di wilayah Kecamatan Pageragoeng, Ciawi, Rajapolah, Cisayong, Cigarontong, Salawu, Taraju, Sodonghilir dan Bojong Gambir (Alzwar dkk., 1992; Supriatna dkk., 1992). Batuan gunungapi tersebut dalam kerangka geohidrologi setempat bertindak sebagai akifer tunggal dan akifer majemuk (Bappeda, 1996). Endapan sedimenter di daerah penelitian meliputi Formasi Bentang (Tmpb), Formasi Kalipucang (Tmkl), Formasi Pamutuan (Tmpa), Anggota Genteng Formasi Jampang (Tmjg), Formasi Jampang (Tomj), dan batuan beku intrusi (Tgd) seperti pada Gambar 2 .

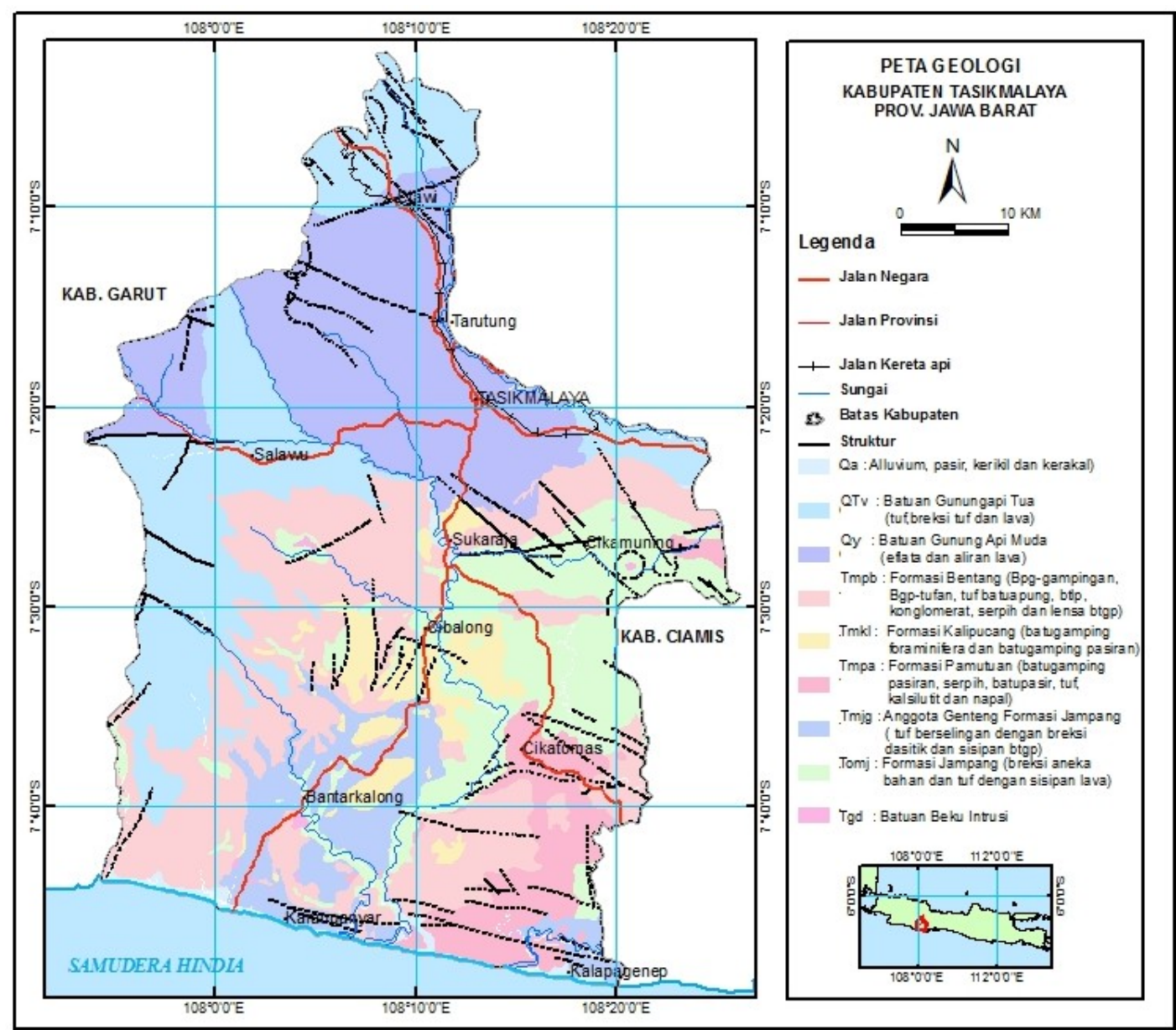

Gambar 2. Peta geologi Tasikmalaya (Alzwar dkk., 1992; Supriatna dkk., 1992 
Formasi Bentang (Tmpb) tersusun atas batupasir gampingan, batupasir tufaan, serpih dan lensa batugamping. Formasi Kalipucang (Tmkl) tersusun atas batugamping foraminifera dan batugamping pasiran. Formasi Pamutuan (Tmpa) tersusun atas batugamping, batugamping pasiran, serpih, batupasir, tufa, lensa batugamping, kalsilutit dan napal. Anggota Genteng Formasi Jampang (Tmgj) tersusun atas tufa berselingan dengan breksi dasitik dan sisipan batugamping. Formasi Jampang (Tomj) tersusun atas batupasir polimik, batupasir tufaan, tufa dan lava. Menurut Hadi (1997), kelompok batuan sedimenter tersebut berfungsi sebagai akifer tertekan dan akifer karstik.

\section{METODOLOGI}

Analisis hidrologi dilakukan dengan menggunakan data dasar daerah aliran sungai (DAS) sebagai satu kesatuan daerah penelitian. DAS merupakan satu sistem hidrologi dimana terdapat hubungan yang sangat erat antara masukan berupa hujan, proses hidrologi DAS, keluaran yang berupa debit sungai dan sedimen yang terangkut (Garng, 1977). Potensi sumberdaya air di suatu DAS dipengaruhi oleh faktor iklim, faktor fisiografi (karakteristik DAS dan karakteristik sungai) dan faktor fisik yang meliputi tataguna lahan, infiltrasi, jenis tanah dan keadaan geologi (Chow et al., 1988).

Analisis kependudukan dilakukan dengan menggunakan data sekunder yang dikeluarkan oleh BPS Provinsi Jawa Barat tahun 2010. Data kependudukan ini diperlukan untuk menghitung kebutuhan air di daerah penelitian. Data iklim meliputi curah hujan, waktu hujan, intensitas curah hujan, rata-rata curah hujan, temperatur, kelembaban, penyinaran matahari, kecepatan angin, evaporasi dan evapotranspirasi. Data iklim yang digunakan adalah data yang terekam dan tersedia di Stasiun Lanud Tasikmalaya, hasil perekaman tahun 1992-1996. Data iklim inilah yang akan memberikan kontribusi dalam perhitungan neraca air (FAO, 1976).

Faktor iklim yang perlu diperhatikan dalam kajian hidrologi ini adalah curah hujan dan penguapan. Curah hujan dan penguapan tersebut digunakan untuk menghitung neraca air yang didasarkan pada hubungan antara aliran ke dalam (input) dan aliran ke luar (output) untuk periode tertentu. Hal ini dipengaruhi oleh jumlah curah hujan yang jatuh di permukaan bumi, kemudian menjadi aliran permukaan (runoff), penguappeluhan (evapotranspirasi) air tanah dan penambahan kelembaban tanah. Keseimbangan tersebut dapat diasumsikan dengan persamaan (Suyono dan Takeda, 1987):

$$
\mathrm{P}=\mathrm{RO}+\mathrm{Ep}+\mathrm{G}+\mathrm{M}
$$

dimana:

$$
\begin{array}{ll}
\mathrm{P}=\text { hujan } & (\mathrm{mm}) \\
\mathrm{RO}=\text { debit aliran permukaan } & (\mathrm{mm}) \\
\mathrm{Ep}=\text { evapotranspirasi } & (\mathrm{mm}) \\
\mathrm{G}=\text { penambahan air tanah } & (\mathrm{mm}) \\
\mathrm{M}=\text { penambahan kadar kelembaban } & (\mathrm{mm})
\end{array}
$$

Evapotranspirasi potensial (PE) adalah potensi untuk terjadinya evaporasi dan transpirasi dalam kondisi iklim tertentu. Menurut Thornthwaite dan Mather (1957), evapotranspirasi bulanan dapat dihitung dengan berdasarkan nilai pendekatan indek panas. PE dihitung berdasarkan pendekatan empiris, yaitu (Thornthwaite dan Mather, 1957):

$$
\begin{aligned}
\mathrm{PE}= & \mathrm{f} * \mathrm{PEc} \\
\mathrm{i}= & (\mathrm{T} / 5)^{1,154} \\
\mathrm{PEc}= & 16(10 \mathrm{~T} / \mathrm{I})^{\mathrm{a}} \\
\mathrm{I}= & 12 \mathrm{i} \\
\mathrm{a}= & 675^{*} 10^{-9} * \mathrm{I}^{3}-77 * 10^{-6 *} \mathrm{I}^{2}+ \\
& 0.1792 * \mathrm{I}+0,4939
\end{aligned}
$$

dimana :

$$
\begin{aligned}
\mathrm{PE} & =\text { evapotranspirasi potensial }(\mathrm{mm}) \\
\mathrm{PEc} & =\text { evapotranspirasi potensial mutlak } \\
\mathrm{f} & =\text { faktor letak lintang } \\
\mathrm{i} & =\text { indek panas bulanan } \\
\mathrm{I} & =\text { total indek panas selama setahun } \\
\mathrm{a} & =\text { nilai tetapan berdasarkan nilai } \mathrm{I} \\
\mathrm{T} & =\text { temperatur bulanan rata-rata }\left({ }^{\circ} \mathrm{C}\right)
\end{aligned}
$$

\section{HASIL DAN PEMBAHASAN}

Penggunaan lahan merupakan bentuk campur tangan manusia terhadap perubahan fisik DAS. Penggunaan lahan di Kabupaten Tasikmalaya yang paling banyak ialah kebun campuran $(35,42$ $\%$ ), sawah teknis $(15,6 \%)$, hutan belukar $(11,9$ $\%)$ dan tegalan (11,6 \%). Permukiman, perkebunan dan sawah non teknis sekitar 5-7 \%, dan penggunaan lain termasuk semak, industri, danau/rawa/kolam dan lain-lain kurang dari $4 \%$. Penggunaan lahan untuk kebun campuran 


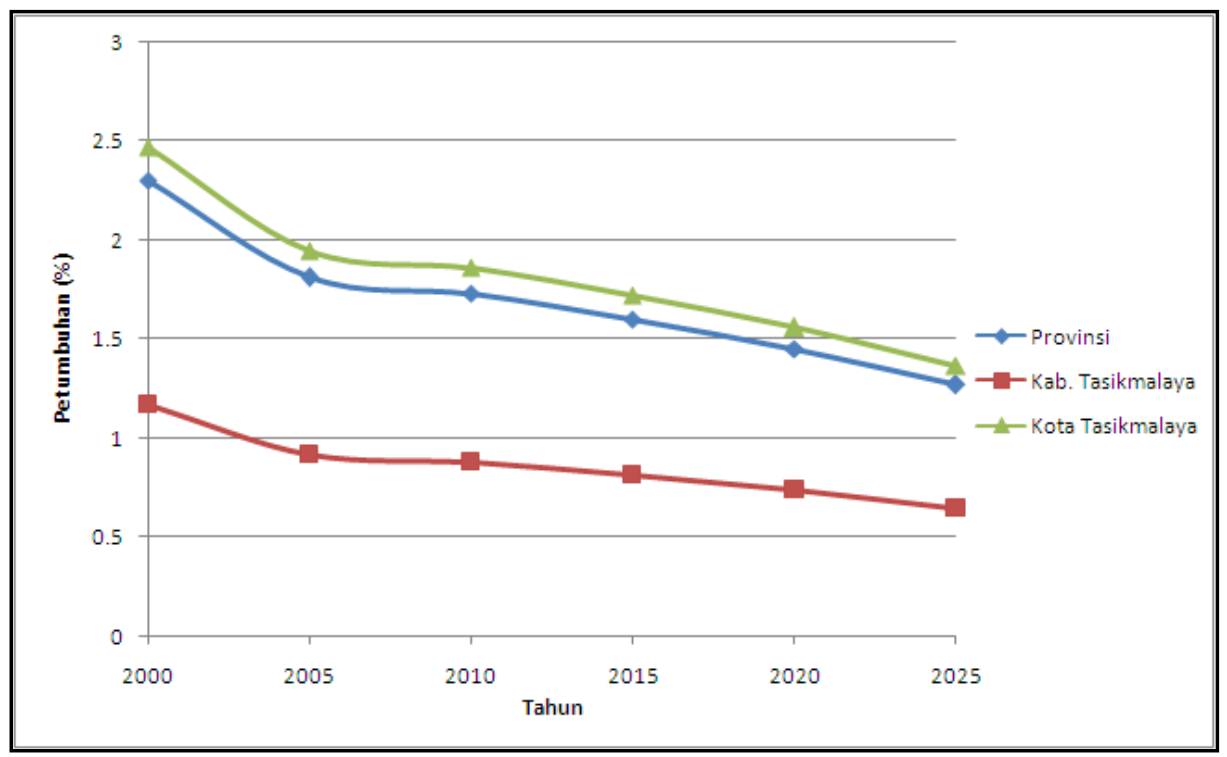

Sumber: BPS Provinsi Jawa Barat, 2010

Gambar 3. Pertumbuhan penduduk di Tasikmalaya

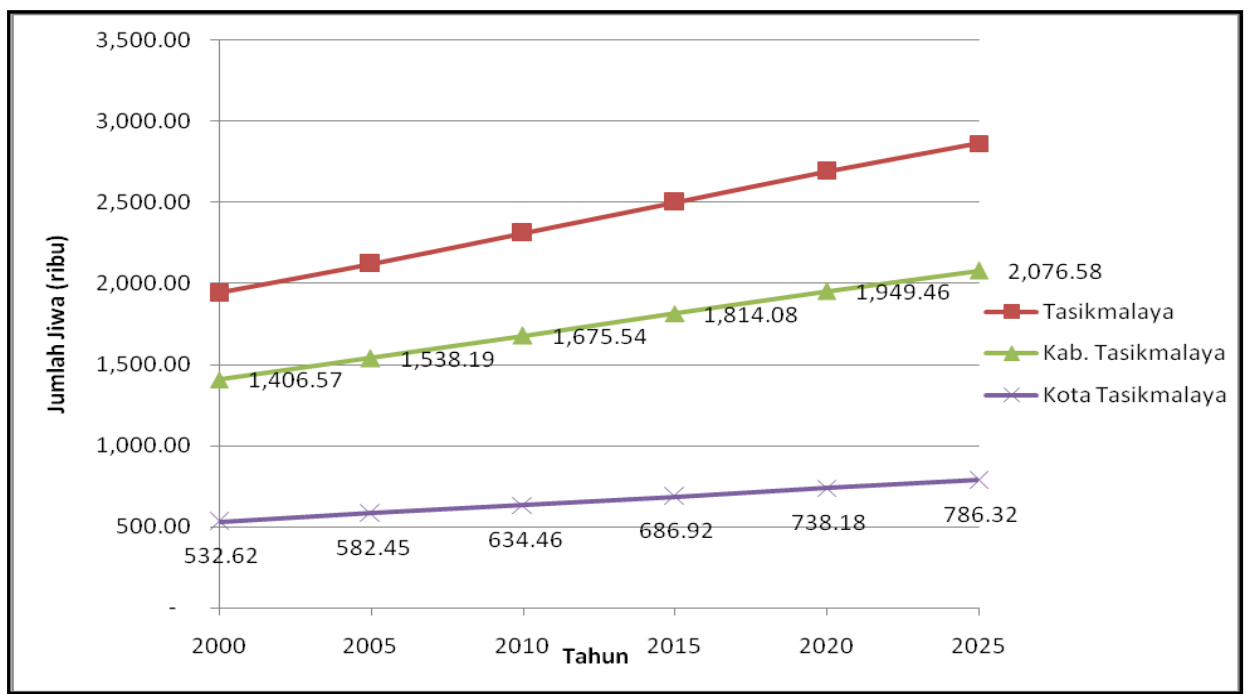

Sumber: BPS Provinsi Jawa Barat, 2010

Gambar 4. Jumlah penduduk di Tasikmalaya

merupakan luasan yang paling besar. Lahan kering sebagian dimanfaatkan untuk pertanian musiman dan tanaman keras. Kebun campuran tersebut tersebar di Kecamatan Karangnunggal, Cibalong dan Sukaraja. Lahan pertanian teknis tersebar di Kecamatan Singaparna, Leuwisari, Indihiang, Rajapolah dan Cibeureum. Hutan tersebar secara setempat-setempat di seluruh kecamatan. Perubahan penggunaan lahan juga terjadi di daerah penelitian yang diakibatkan oleh adanya pertumbuhan kawasan permukiman, industri, perkebunan dan pertanian.

Jumlah penduduk Kabupaten dan Kota Tasikmalaya hasil sensus penduduk Tahun 2010 sebesar 2.309.968 jiwa, masing-masing adalah 1.675.544 jiwa di Kabupaten Tasikmalaya dan kota Tasikmalaya sebanyak 634.424 jiwa (BPS- 
Jabar, 2010). Gambaran pertumbuhan penduduk Kabupaten dan Kota Tasikmalaya ditunjukkan pada Gambar 3. Tampak bahwa laju pertumbuhan penduduk adalah sebesar $0,88 \%$ (Kabupaten Tasikmalaya) dan 1,86 \% (Kota Tasikmalaya). Dari tahun ke tahun laju pertumbuhan penduduk cenderung turun, namun demikian jumlah penduduk selalu naik. Prediksi jumlah penduduk di Kabupaten dan Kota Tasikmalaya disajikan pada Gambar 4. Apabila pertambahan penduduk mengikuti kecenderungan Provinsi Jawa Barat, pada tahun 2025 jumlah penduduk di Kabupaten 2.076.582 jiwa dan Kota Tasikmalaya 786.321 jiwa, sehingga jumlah penduduk di Kabupaten dan Kota Tasikmalaya sebanyak 2.862.902 jiwa.

Daerah penelitian meliputi 3 DAS utama (Gambar 5), ketiga DAS tersebut adalah DAS
Ciwulan dengan luas $236.6 \mathrm{~km}^{2}$, DAS Cimedang $\left(200,0 \mathrm{~km}^{2}\right)$ dan DAS Cilangla $\left(176,7 \mathrm{~km}^{2}\right)$. DAS Ciwulan merupakan sungai terbesar yang membelah Kabupaten Tasikmalaya. DAS Ciwulan berhulu dari Gunung Kracak, Galunggung, Bungbulang dan Balitiganar. Ratarata debit harian berkisar antara 2,37 sampai 26,5 $\mathrm{m}^{3} /$ detik. Aliran air sungai maksimum yang pernah terjadi sebesar $136,67 \mathrm{~m}^{3} /$ detik dan minimum $0,8 \mathrm{~m}^{3} /$ detik. DAS Ciwulan menempati $38,6 \%$ dari luas daerah penelitian. DAS Cimedang merupakan sungai yang terletak pada perbatasan antara Kabupaten Tasikmalaya dan Kabupaten Ciamis. Rata-rata aliran harian berkisar antara 1,9 sampai $10,2 \mathrm{~m}^{3} /$ detik. Debit maksimum DAS Cimedang sebesar 89,44 $\mathrm{m}^{3} /$ detik dan debit minimum $0,82 \mathrm{~m}^{3} /$ detik. DAS Cimedang ini menempati $32,6 \%$ dari luas daerah

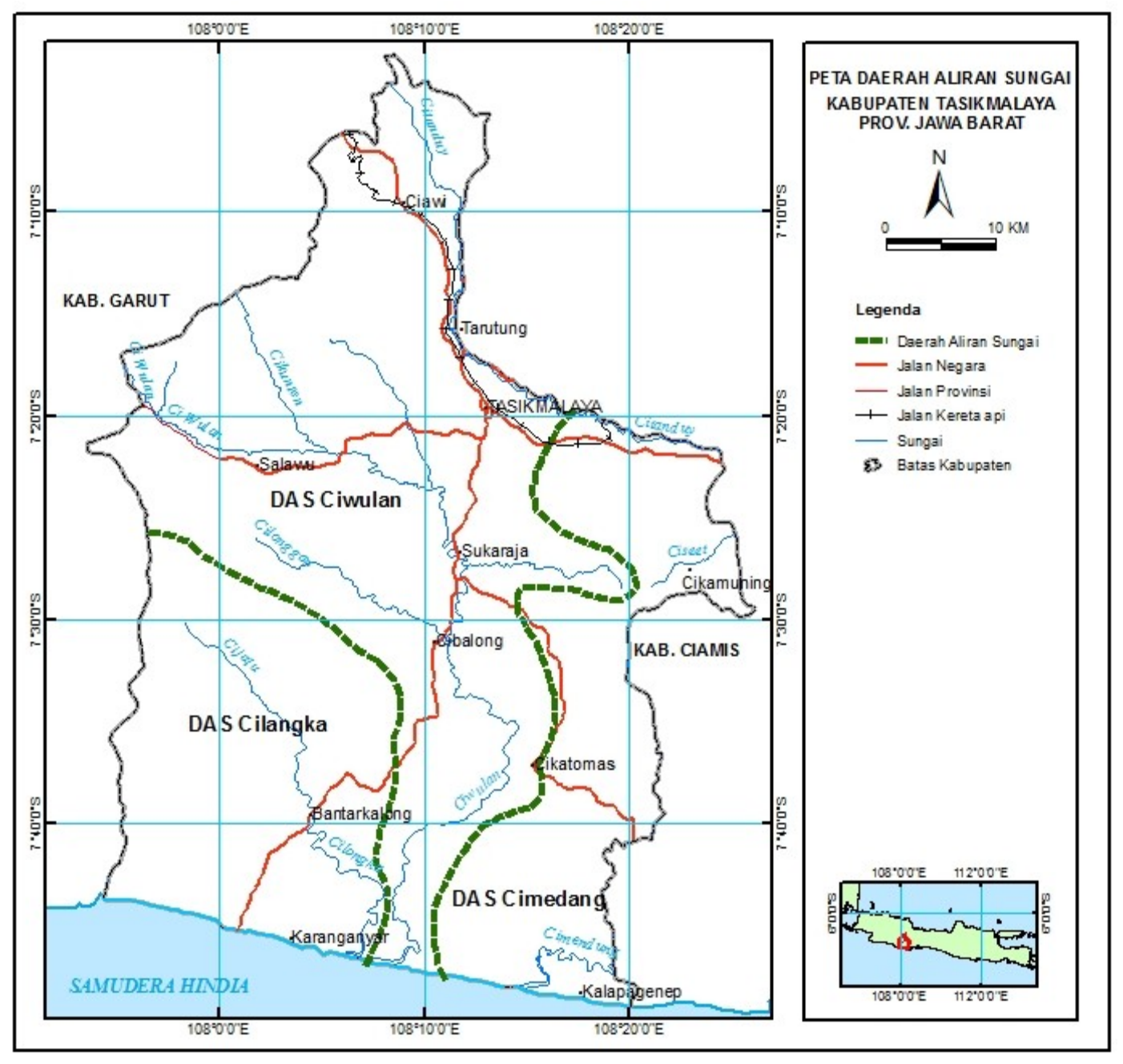

Gambar 5. Peta daerah aliran sungai (DAS) di Tasikmalaya 
penelitian. DAS Cilangla yang berhulu di Sukahurip memiliki rata-rata debit harian 1,77 sampai $23,6 \mathrm{~m}^{3} /$ detik. Fluktuasi tinggi muka maksimum dan minimum air sungai dapat sangat mencolok. Aliran terkecil muka air sebesar 0,46 $\mathrm{m}$ dengan debit 1,05 m3/detik. Aliran air sungai terbesar yang pernah terjadi adalah dengan tinggi muka air $4,31 \mathrm{~m}$ dan debit $754 \mathrm{~m}^{3} /$ detik. DAS Cilangla menempati $28,8 \%$ dari luas daerah penelitian.

\section{Klimatologi}

Kondisi iklim di suatu daerah sangat dipengaruhi oleh curah hujan, temperatur, kelembaban udara, kecepatan angin, penyinaran matahari, dan penguapan. Iklim yang berpengaruh di Kabupaten Tasikmalaya adalah iklim tropis dengan rata-rata curah hujan $2.532 \mathrm{~mm} / \mathrm{tahun}$, dengan hujan efektif selama satu tahun adalah 128 hari. Curah hujan tertinggi terjadi pada bulan November yaitu $320 \mathrm{~mm}$ dan terendah pada bulan Agustus, yaitu $92 \mathrm{~mm}$. Jumlah bulan kering di Kabupaten Tasikmalaya berlangsung pada Bulan Agustus (1 bulan) dan bulan basah dari bulan September hingga Juli (11 bulan) atau $\boldsymbol{Q}=$ $91.67 \%$, maka tipe curah hujan termasuk dalam klasifikasi $\boldsymbol{A}$ atau sangat basah. (Dam et al., 1972). Yang dimaksud dengan Q adalah perbandingan antara bulan basah dengan bulan kering. Temperatur maksimum di daerah penelitian berkisar antara $29,80-31,1^{\circ} \mathrm{C}$ dan minimum berkisar antara $17,28-21,28^{\circ} \mathrm{C}$, sedangkan rata-rata berkisar antara 23,42$24,80^{\circ} \mathrm{C}$ (Tabel 1).

Kelembaban udara merupakan komponen penting pada unsur iklim sebagai indikator kapasitas potensial atmosfir, pengatur temperatur dan sumber asal hujan. Kelembaban di wilayah kerja disajikan sebagai kelembaban relatif, yang dihitung dari perbandingan hasil pembacaan alat ukur bola basah dan bola kering. Hasil perhitungan kelembaban udara rata-rata dapat dilihat pada Tabel 1. Kelembaban udara maksimum di daerah penelitian berkisar antara 94,6-97,4 \% umumnya terjadi pada pagi hari. Kelembaban minimum berkisar antara 68,4-73,8 $\%$ biasanya terjadi pada siang hari. Rata-rata kelembaban berkisar antara 87,8-89,6 \%. Kecepatan angin rata-rata berkisar antara 3,13 $5,73 \mathrm{~km} / \mathrm{jam}$ dan kecepatan angin maksimum pada bulan Maret sebesar $35 \mathrm{~km} / \mathrm{jam}$ dari arah tenggara (SE).

\section{Evapotranspirasi}

Peristiwa berubahnya air menjadi uap dan bergerak dari permukaan tanah ke udara dan peristiwa penguapan dari tanaman disebut evapotranspirasi. Evapotranspirasi merupakan faktor yang penting untuk menentukan kebutuhan air pada tanaman dalam perencanaan irigasi dan merupakan proses dalam siklus hidrologi. Hal ini sangat dipengaruhi oleh unsur-unsur iklim yaitu suhu udara, kelembaban, kecepatan angin dan lain-lain. Data evaporasi diperlukan dalam perhitungan evapotranspirasi. Karena di daerah penelitian tidak didapatkan data evaporasi, maka penentuan evapotranspirasi dilakukan dengan cara menggunakan rumus yang dikemukakan oleh Thornthwaite dan Mather (1957). Perhitungannya didasarkan pada suhu udara ratarata bulanan, standar bulan 30 hari dan jam penyinaran 12 jam. Berdasarkan hasil perhitungan diperoleh nilai evapotranspirasi seperti pada Tabel 2. Hasil perhitungan menunjukkan bahwa evapotranspirasi harian ratarata adalah sebesar $3,59 \mathrm{~mm}$. Evapotranspirasi bulanan berkisar antara 96 sampai $116 \mathrm{~mm} /$ bulan. Total evapotranspirasi setahun sebesar 1.307,22 $\mathrm{mm}$. Evapotranspirasi tertinggi terjadi pada bulan Maret sebesar 115,47 mm, yang terjadi pada saat musim penghujan. Dapat disimpulkan bahwa evapotranspirasi pada dasarnya mengikuti pola curah hujan. Evapotranspirasi minimum terjadi pada bulan Agustus sebesar 98,14 mm di musim kemarau.

\section{Neraca Air}

Analisis neraca air dimaksudkan untuk mengetahui jumlah besaran komponenkomponen hidroklimatologi, terutama meliputi besaran curah hujan, evapotranspirasi, limpasan air permukaan (surface run-off), dan perkolasi (pengimbuhan air tanah). Hasil selengkapnya perhitungan evapotranspirasi bulanan dapat dilihat pada Tabel 3. Gambaran hubungan antara curah hujan dan evapotranspirasi dapat dilihat pada Gambar 6.

Curah hujan rata-rata bulanan daerah penelitian berkisar antara 92 sampai $320 \mathrm{~mm}$, dengan jumlah hujan tahunan $2532 \mathrm{~mm}$. Temperatur bulanan berkisar antara 23 sampai $25^{\circ} \mathrm{C}$. 
Tabel 1. Data klimatologi tahun $1992-1996$

Stasiun Lanud Tasikmalaya dan SMPK Nariewattie Tasikmalaya

\begin{tabular}{|c|c|c|c|c|c|c|c|c|c|c|c|c|c|c|c|}
\hline \multirow[t]{2}{*}{ BULAN } & \multicolumn{4}{|c|}{ TEMPERATUR $\left({ }^{\circ} \mathrm{C}\right)$} & \multicolumn{2}{|c|}{ MAKSIMUM } & \multicolumn{2}{|c|}{ MINIMUM } & \multicolumn{4}{|c|}{ KELEMBABAN (\%) } & \multicolumn{2}{|c|}{\begin{tabular}{|c}
$\begin{array}{c}\text { KEC. ANGIN } \\
(\mathrm{km} / \mathbf{j a m})\end{array}$ \\
\end{tabular}} & \multirow[t]{2}{*}{$\begin{array}{l}\text { ARAH } \\
\text { ANGIN }\end{array}$} \\
\hline & 07.00 & 14.00 & 18.00 & $\underset{2}{\text { RATA }}$ & RATA $^{2}$ & $\mathrm{ABS}$ & RATA $^{2}$ & $\mathrm{ABS}$ & 07.00 & 14.00 & 18.00 & $\underset{2}{\text { RATA }}$ & $\underset{2}{\operatorname{RATA}}$ & MAK & \\
\hline Januari & 22,14 & 28,82 & 25,02 & 24,56 & 29,68 & 1,76 & 21,18 & 20,24 & 97,40 & 70,60 & 88,40 & 88,60 & 3,55 & 23 & NW \\
\hline Februari & 22,04 & 29,36 & 25,10 & 24,66 & 30,12 & 1,72 & 21,46 & 19,92 & 97,00 & 69,00 & 87,40 & 88,00 & 4,39 & 30 & $\mathrm{NE}$ \\
\hline Maret & 22,96 & 29,22 & 25,06 & 24,80 & 30,02 & 31,76 & 21,56 & 20,36 & 97,00 & 67,80 & 87,20 & 87,40 & 4,71 & 35 & SE \\
\hline April & 22,50 & 29,06 & 24,92 & 24,78 & 29,88 & 31,88 & 21,88 & 20,84 & 97,20 & 69,60 & 87,00 & 87,80 & 4,53 & 16 & $\mathrm{NE}$ \\
\hline Mei & 22,48 & 29,28 & 25,08 & 24,70 & 29,94 & 31,72 & 21,52 & 19,44 & 97,00 & 68,80 & 87,80 & 87,00 & 5,45 & 20 & $\mathrm{NE}$ \\
\hline Juni & 21,62 & 28,10 & 24,50 & 24,22 & 29,40 & 31,40 & 21,04 & 19,20 & 96,80 & 70,40 & 89,00 & 87,80 & 5,73 & 25 & E \\
\hline Juli & 20,40 & 28,18 & 24,54 & 23,42 & 29,30 & 29,80 & 19,50 & 17,68 & 95,60 & 70,20 & 88,40 & 87,00 & 4,52 & 25 & $\mathrm{E}$ \\
\hline Agustus & 20,98 & 27,74 & 24,40 & 23,54 & 28,38 & 30,92 & 20,22 & 17,28 & 94,60 & 73,40 & 86,80 & 87,00 & 5,19 & 25 & $\mathrm{E}$ \\
\hline September & 21,50 & 28,06 & 24,50 & 23,82 & 28,58 & 30,64 & 20,68 & 18,12 & 95,40 & 68,40 & 87,20 & 86,80 & 4,80 & 20 & $\mathrm{NE}$ \\
\hline Oktober & 22,38 & 28,14 & 24,60 & 24,38 & 28,84 & 31,32 & 21,68 & 20,00 & 95,80 & 72,00 & 87,80 & 87,80 & 4,19 & 30 & $\mathrm{NE}$ \\
\hline November & 22,76 & 28,48 & 24,58 & 24,62 & 29,18 & 31,96 & 21,96 & 21,28 & 97,20 & 73,80 & 88,80 & 89,60 & 3,87 & 20 & SE \\
\hline Desember & 22,26 & 28,36 & 24,64 & 24,48 & 28,68 & 31,68 & 21,68 & 19,52 & 95,40 & 70,80 & 87,80 & 88,00 & 3,13 & 18 & SE \\
\hline
\end{tabular}


Tabel 2. Hasil perhitungan evapotranspirasi rata-rata di Kabupaten Tasikmalaya

\begin{tabular}{|c|c|c|c|r|c|r|r|c|}
\hline BULAN & T & i & a & \multicolumn{1}{c|}{ Ep* } & f & \multicolumn{3}{|c|}{ Ep } \\
\hline & $\left({ }^{\circ} \mathrm{C}\right)$ & & & $(\mathrm{cm} / \mathrm{bl})$ & & $(\mathrm{cm} / \mathrm{bl})$ & $(\mathrm{mm} / \mathrm{bl})$ & $(\mathrm{mm} / \mathrm{hr})$ \\
\hline Januari & 24,56 & 11,16 & 3,12 & 10,72 & 1,045 & 11,20 & 112,02 & 3,61 \\
\hline Februari & 24,66 & 11,23 & 3,12 & 10,86 & 1,045 & 11,34 & 113,45 & 4,05 \\
\hline Maret & 24,80 & 11,30 & 3,12 & 11,05 & 1,045 & 11,55 & 115,47 & 3,72 \\
\hline April & 24,78 & 11,30 & 3,12 & 11,02 & 1,045 & 11,52 & 115,18 & 3,84 \\
\hline Mei & 24,70 & 11,23 & 3,12 & 10,91 & 1,045 & 11,40 & 114,02 & 3,68 \\
\hline Juni & 24,22 & 10,82 & 3,12 & 10,26 & 1,045 & 10,73 & 107,26 & 3,58 \\
\hline Juli & 23,42 & 10,95 & 3,12 & 9,24 & 1,045 & 9,66 & 96,59 & 3,12 \\
\hline Agustus & 23,54 & 11,02 & 3,12 & 9,39 & 1,045 & 9,81 & 98,14 & 3,17 \\
\hline September & 23,82 & 11,30 & 3,12 & 9,74 & 1,045 & 10,18 & 101,83 & 3,39 \\
\hline Oktober & 24,38 & 10,95 & 3,12 & 10,48 & 1,045 & 10,95 & 109,48 & 3,53 \\
\hline November & 24,62 & 11,16 & 3,12 & 10,80 & 1,045 & 11,29 & 112,88 & 3,76 \\
\hline Desember & 24,48 & 11,02 & 3,12 & 10,61 & 1,045 & 11,09 & 110,89 & 3,58 \\
\hline & \multicolumn{2}{|c|}{$\mathrm{I}=133,44$} & & & & & 1307,22 & \\
\hline
\end{tabular}

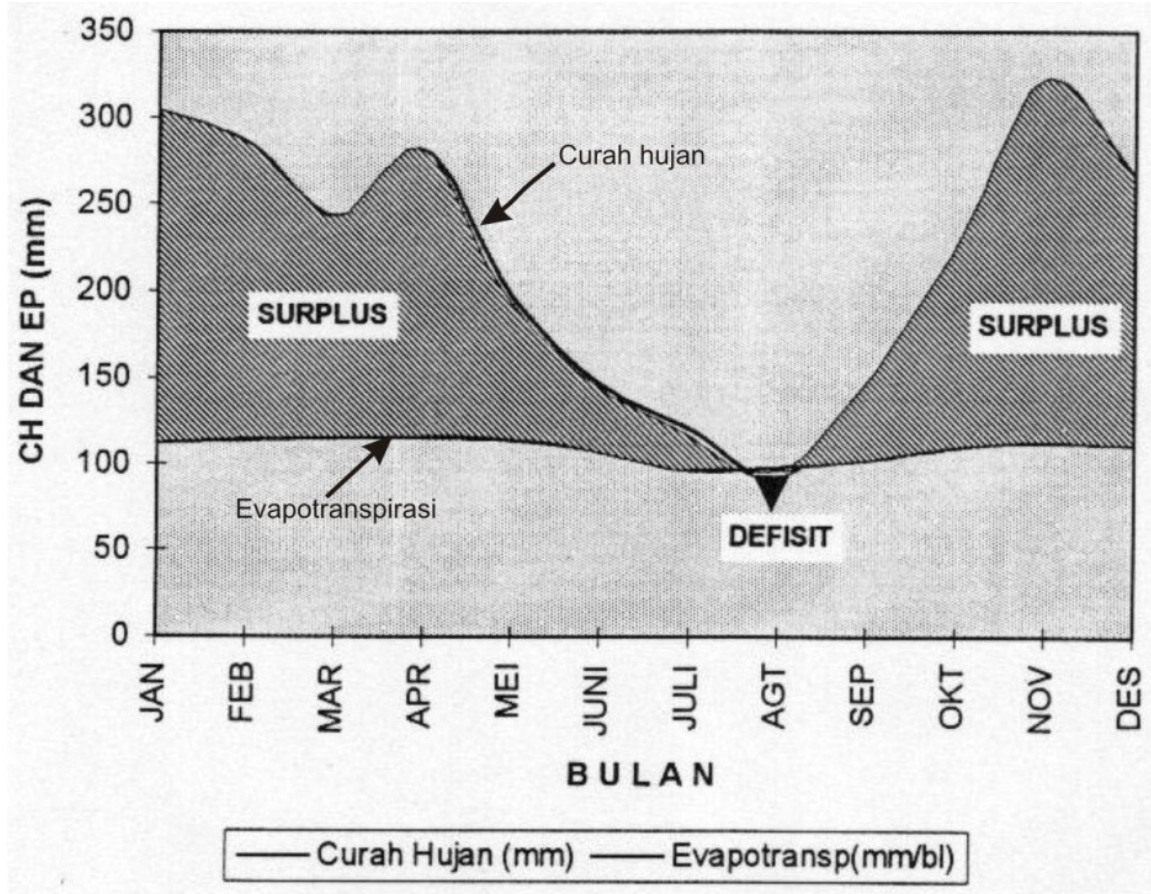

Gambar 6. Perbandingan antara curah hujan dan evapotranspirasi di Kabupaten Tasikmalaya 
Tabel 3. Rata-rata curah hujan dan evapotranspirasi di Kabupaten Tasikmalaya tahun $1992-1996$

\begin{tabular}{|c|c|c|}
\hline Bulan & $\begin{array}{c}\text { Curah Hujan } \\
(\mathrm{mm})\end{array}$ & $\begin{array}{c}\text { Evapotransp } \\
(\mathrm{mm} / \mathrm{bl})\end{array}$ \\
\hline Januari & 303 & 112,02 \\
\hline Februari & 286 & 113,45 \\
\hline Maret & 243 & 115,47 \\
\hline April & 281 & 115,18 \\
\hline Mei & 197 & 114,02 \\
\hline Juni & 146 & 107,26 \\
\hline Juli & 120 & 96,59 \\
\hline Agustus & 92 & 98,14 \\
\hline September & 143 & 101,83 \\
\hline Oktober & 221 & 109,48 \\
\hline November & 320 & 112,88 \\
\hline Desember & 266 & 110,89 \\
\hline Jumlah & 2532 & 1307,22 \\
\hline
\end{tabular}

Evapotranspirasi bulanan berkisar antara 96 sampai $116 \mathrm{~mm}$, sedangkan jumlah setahun 1307 $\mathrm{mm}$.

Selisih antara jumlah curah hujan dan evapotranspirasi menunjukkan bulan yang mempunyai kelebihan air (surplus) maupun bulan-bulan yang kekurangan air (deficit) (Gambar 6). Banyaknya simpanan air dalam tanah sangat tergantung pada tektur tanah dan jangkauan perakaran dari vegetasi maupun penutup lahan yang ada. Dengan memperhitungkan luas jenis tanah dan luas penutup lahan, yaitu sawah, tegalan, hutan, perkebunan dan permukiman timbunan air yang terdapat di bawah permukaan tanah sebesar 250 mm. Timbunan air pada daerah aliran sungai terwakili yaitu DAS Ciwulan antara 6-31,3 $\mathrm{m}^{3} /$ detik, DAS Cimedang berkisar antara 4-26,5 $\mathrm{m}^{3} /$ detik dan DAS Cilangla adalah 4-23,4 $\mathrm{m}^{3} /$ detik. Pada bulan-bulan hujan mulai berkurang maka timbunan air yang ada di dalam tanah akan mengalami kekurangan air. Hal ini disebabkan evapotranspirasi melebihi jumlah curah hujan, sehingga cadangan air di dalam tanah akan digunakan untuk kebutuhan evapotranspirasi.

Surplus air hujan adalah selisih antara curah hujan dengan evapotranspirasi. Pada bulan Agustus jumlah curah hujan lebih kecil dari evapotranspirasi, maka terjadi defisit air (Gambar 6), dan akan terjadi sampai curah hujan melebihi evapotranspirasi. Surplus air yang ada di permukaan tanah sebagian akan meresap ke dalam tanah. Jumlah yang mampu meresap ke dalam tanah dalam perhitungan ini sebesar $50 \%$ dan sisa surplus air tersebut meresap pada bulan berikutnya. Berdasar hasil perhitungan, terdapat surplus air antara $23 \mathrm{~mm}$ sampai $207 \mathrm{~mm}$. Dengan luas wilayah 2.680,5 $\mathrm{km}^{2}$, maka cadangan air bulanan berkisar antara 1.306.515 $\mathrm{m}^{3}$ hingga $11.758 .655 \mathrm{~m}^{3}$. Cadangan air pada DAS Cilangla dengan luas sekitar $176,7 \mathrm{~km}^{2}$ berkisar antara $1.354,7 \mathrm{~m}^{3} /$ hari-12.192,3 $\mathrm{m}^{3} /$ hari. Cadangan DAS Ciwulan dengan luas sekitar $236,6 \mathrm{~km}^{2}$ antara $1.813,9 \mathrm{~m}^{3} /$ hari-16.325,4 $\mathrm{m}^{3} /$ hari. DAS Cimedang dengan luas wilayah sekitar $200 \mathrm{~km}^{2}$ cadangan air berkisar antara $1.533,3 \mathrm{~m}^{3} /$ hari-13.800,0 $\mathrm{m}^{3} /$ hari (Tabel 4). 


\section{RISET}

Tabel 4. Neraca sumberdaya air di Kabupaten Tasikmalaya (Per DAS)

\begin{tabular}{|c|c|c|c|c|c|c|c|c|c|c|c|c|c|c|}
\hline KOMPONEN & Satuan & JAN & FEB & MAR & APR & MEI & JUNI & JULI & AGS & SEP & OKT & NOV & DES & Jumlah \\
\hline Temperatur (T) & $\left({ }^{\circ} \mathrm{C}\right)$ & 24,56 & 24,66 & 24,8 & 24,78 & 24,7 & 24,22 & 23,43 & 23,54 & 23,82 & 24,38 & 24,62 & 24,48 & \\
\hline Curah hujan $(\mathrm{P})$ & $(\mathrm{mm})$ & 303 & 286 & 243 & 281 & 197 & 146 & 120 & 92 & 143 & 221 & 320 & 266 & 2618 \\
\hline Evapotranspirasi (EP) & $(\mathrm{mm})$ & 112 & 113 & 115 & 115 & 114 & 107 & 97 & 98 & 102 & 109 & 113 & 111 & 1306 \\
\hline$P$ - EP & $(\mathrm{mm})$ & 191 & 173 & 128 & 166 & 83 & 39 & 23 & -6 & 41 & 112 & 207 & 155 & 1312 \\
\hline APWL & $(\mathrm{mm})$ & 0 & 0 & 0 & 0 & 0 & 0 & 0 & -6 & 0 & 0 & 0 & 0 & \\
\hline ST & $(\mathrm{mm})$ & 250 & 250 & 250 & 250 & 250 & 250 & 250 & 244 & 250 & 250 & 250 & 250 & \\
\hline DST & $(\mathrm{mm})$ & 0 & 0 & 0 & 0 & 0 & 0 & -4 & 0 & 0 & 0 & 0 & 0 & \\
\hline $\mathrm{AE}$ & $(\mathrm{mm})$ & 112 & 113 & 115 & 115 & 114 & 107 & 125 & 98 & 102 & 109 & 113 & 111 & 1334 \\
\hline $\mathrm{S}$ & $(\mathrm{mm})$ & 191 & 173 & 128 & 166 & 83 & 39 & 23 & 0 & 41 & 112 & 207 & 155 & 1318 \\
\hline Runoff & $(\mathrm{mm})$ & 338,02 & 341,99 & 298,97 & 315,47 & 240,72 & 159,35 & 102,67 & 39,83 & 60,92 & 142,45 & 278,21 & 294,08 & 2612,68 \\
\hline \multicolumn{15}{|l|}{ Run off masing-masing DAS } \\
\hline DAS Ciwulan luas $236,6 \mathrm{~km}^{2}$ & $\mathrm{~m}^{3} / \mathrm{det}$ & 30,85 & 31,22 & 27,29 & 28,80 & 21,97 & 14,55 & 9,37 & 3,64 & 5,56 & 13,00 & 25,40 & 26,84 & 238,49 \\
\hline DAS Cimedang luas $200 \mathrm{~km}^{2}$ & $\mathrm{~m}^{3} / \mathrm{det}$ & 26,08 & 26,39 & 23,07 & 24,34 & 18,57 & 12,30 & 7,92 & 3,07 & 4,70 & 10,99 & 21,47 & 22,69 & 201,60 \\
\hline DAS Cilangla luas $176,7 \mathrm{~km} 2$ & $\mathrm{~m} 3 / \mathrm{det}$ & 23,04 & 23,31 & 20,38 & 21,51 & 16,41 & 10,86 & 7,00 & 2,72 & 4,15 & 9,71 & 18,97 & 20,05 & 178,11 \\
\hline
\end{tabular}

Dimana :

$\mathrm{P}-\mathrm{PE}=$ Selisih hujan dan evapotranspirasi

APWL = Accumulated potential water loss

ST $=$ Storage

DST $=$ Perubahan kelembaban tanah

$\mathrm{AE}=$ Actual evapotranspiration

$\mathrm{S} \quad=$ Moisture surplus 


\section{KESIMPULAN}

Pada DAS Cilangla dengan luas DAS $176,7 \mathrm{~km}^{2}$, debit aliran sungai adalah $4-23,4 \mathrm{~m}^{3} /$ detik. Untuk DAS Ciwulan dengan luas $236,6 \mathrm{~km}^{2}$, debit aliran sungai adalah $6-31,3 \mathrm{~m}^{3} /$ detik, dan DAS Cimedang dengan luas $200 \mathrm{~km}^{2}$ debit aliran sungai adalah 4-26,5 $\mathrm{m}^{3} /$ detik. Dengan evapotranspirasi harian rata-rata $3,59 \mathrm{~mm}$ dan evapotranspirasi bulanan 96 sampai 116 $\mathrm{mm} /$ bulan, maka total evapotranspirasi dalam satu tahun sebesar 1307,22 mm. Evapotranspirasi tertinggi terjadi pada bulan Februari sebesar $115,47 \mathrm{~mm}$.

Curah hujan rata-rata bulanan antara 92-320 mm dan temperatur bulanan $23^{\circ} \mathrm{C}$ sampai $25^{\circ} \mathrm{C}$. Surplus air adalah $23 \mathrm{~mm}$ sampai $207 \mathrm{~mm}$. Dengan luas wilayah Kabupaten Tasikmalaya 2680,5 $\mathrm{km}^{2}$, cadangan air bulanan adalah $1.306 .515 \mathrm{~m}^{3}$ hingga $11.758 .655 \mathrm{~m}^{3}$. Dengan estimasi kebutuhan air 100 liter/hari/orang, maka diperkirakan untuk memenuhi 2.221.502 jiwa/hari diperlukan 222.150.200 liter/hari atau $222.150 \mathrm{~m}^{3} /$ hari. Cadangan air yang terdapat di Kabupaten Tasikmalaya adalah 43.550,5 m3/hr$391.955,17 \mathrm{~m}^{3} / \mathrm{hr}$. Hasil perhitungan menunjukkan bahwa pada bulan sangat kering terjadi kekurangan air sekitar $178.600 \mathrm{~m}^{3} / \mathrm{hr}$. Sedangkan pada musim basah akan terjadi kelebihan air sebesar $169.805 \mathrm{~m}^{3} / \mathrm{hr}$. Kebutuhan untuk pertanian sebesar 1 liter/detik/ha. Dengan demikian kelebihan air pada musim basah ini dapat digunakan untuk pertanian sekitar 117.920 Ha.

Jumlah cadangan air yang tersedia ini merupakan hasil analisa dengan asumsi pengelolaan dan pemanfaatan lahan tetap seperti kondisi sekarang. Namun apabila penggunaan lahan terdegradasi, jumlah cadangan air yang tersedia dapat berkurang. Perubahan tutupan lahan pada daerah imbuhan menyebabkan debit air mengecil, untuk itu fungsi lahan perlu dijaga agar tidak terdegradasi.

\section{UCAPAN TERIMAKASIH}

Pada kesempatan ini, dengan selesainya dan diterbitkan tulisan ini, penulis ingin mengucapkan terimakasih atas bantuan dari rekan-rekan. Tidak lupa kami ucapkan terimakasih juga kepada Drs. Saifudin atas diskusi dan datanya, juga kepada Ir Sudaryanto, MT, APU atas diskusi dan saran penyempurnaan tulisan ini.

\section{DAFTAR PUSTAKA}

Alzwar, M., Akbar N dan Bachri S, 1992, Peta Geologi Lembar Garut dan Pameungpeuk, skala 1: 100.000, Pusat Penelitian dan Pengembangan Geologi, ESDM, Bandung.

Badan Pusat Statistik (BPS) Jawa Barat, 2010, Sensus Penduduk Tahun 2010: data Agregat Per Kabupaten/Kota Provinsi Jawa Barat, BPS Provinsi Jawa Barat

Bappeda, 1996, Penelitian Sumber Air Bawah Tanah di Tasikmalaya Selatan, Kerjasama Bappeda Kabupaten Tasikmalaya Direktorat Geologi Tata Lingkungan, ESDM, Bandung, (lap. Tak dipublikasikan)

Chow, V.T. et.al, 1988. "Applied Hydrology". Mc. Graw Hill Book Co., New York, Toronto, London, p.326

Dam, Van J.C., W. R. Raaff and A Volker, 1972, "Clymatology", ILRI Wagenegen Netherlands.

Djuwansah, M.R dan Rusydi, A.F., 2012. Daya Dukung Sumber Daya Air (DDSA) Kota Cirebon dan Sekitarnya, Buletin Geologi Tata Lingkungan, Volume 22 Nomor 1, April 2012: 35-48.

FAO, 1976. Hydrology for soil and water conservation in coastal regions of north Africa. In: Hydrological Techniques for Upstream Conservation, USDA-SCS North Africa project. In: Conservation Guide 2. S.H. Kunkle and J.L. Thames (eds). Rome

Garng, S.K. 1977, Water resources Hydrology“, Publisher New Delhi.

Hadi, S.I, 1997, Potensi Sumberdaya Airtanah Daerah Tasikmalaya Selatan, Pusat Penelitian dan Pengembangan Geoteknologi, LIPI, Bandung, (lap. Tak dipublikasikan)

Pemerintah Kabupaten Tasikmalaya (Pemkab Tasikmalaya), 2012, Peraturan Daerah 
Nomor. 2 Tahun 2012 Tentang Rencana Tata Ruang Wilayah Kabupaten Tasikmalaya, Pemerintah Kabupaten Tasikmalaya.

Sonjaya Marenda I, 2008. Identifikasi Pergeseran Sektor Unggulan Kecamatan di Kabupaten Tasikmalaya Jawa Barat Untuk Evaluasi Kebijakan Pertanian, Jurnal Agrikultura, Vol. 13 No. 3 tahun 2008, Unpad

Supriatna S., Sarmili S., Sudana D., dan Koswara, 1992, Peta Geologi Lembar
Karangnunggal, skala 1: 100.000, Pusat Penelitian dan Pengembangan Geologi, ESDM, Bandung.

Suyono S. dan Takeda, K., 1987, "Hidrologi Untuk Pengairan", Jakarta, PT Pradnya Paramita.

Thornthwaite, C.W., and J. R. Mather, 1957, Instruction and Table For Computing Potential Evapotranspiratin and the Water Balance, Publication in Climatology, Volume X, New Jersey 